\title{
Effect of Fiscal Instability on Economic Growth in Nigeria
}

\author{
Akanni K.A* , Osinowo O.H. \\ Department of Agricultural Economics ,College of Agricultural Sciences Olabisi Onabanjo University,PMB 2002, \\ Ago-Iwoye, Ogun State,Nigeria \\ *Corresponding Author: akannikunle2003@yahoo.co.uk
}

Copyright (c) 2013 Horizon Research Publishing All rights reserved.

\begin{abstract}
This study examined the effect of fiscal instability on economic growth in Nigeria for the period of 1970-2010.The cyclical effect of fiscal spending components were measured using the Hodrick Prescot (HP)-filtered fiscal spending components and output with the correlation technique. Results indicated that between 1970 and 1985 , both the real gross domestic product and real total fiscal spending were highly volatile. However, total fiscal spending appears to be countercyclical between 1970 to 1986. But from 1987 to 2010, the variation in total fiscal spending was relatively stationary while real output was still relatively unstable. Fiscal discipline is required to ensure a sustainably stable economic environment in Nigeria.
\end{abstract}

Keywords Business Cycles; Economic growth; Fluctuations; Fiscal Spending; Real GDP

JEL Classification Code:E63 (Comparative or Joint Analysis of Fiscal \& Monetary Policy stabilization)

\section{Introduction}

The need for a more stable macroeconomic environment through sound fiscal and monetary actions is still very paramount in the world of research. Besides the challenges posed by globalization to the domestic economy, it has been empirically argued that instability and uncertainty in any economy impede long term growth and have high welfare cost (Ramey and Ramey, 1995; Serven, 1998; Martin and Rogers, 2000; Mobarak, 2001; Fatás, 2002; Fatás and Mihov, 2003; Hnatkovska and Loayza, 2005 and; Adefeso and Mobolaji, 2010). Macroeconomic dynamics in Nigeria have been dominated in the past by fiscal instability. There has been a strong deficit stemming from government revenue volatility. As a result, monetary authority has been forced to implement neutralizing monetary policies leading to macroeconomic instability (Obiyeluaku, 2006). The effect of fiscal instability on economic growth is a controversial and long-standing topic in economic theory, empirical research, and economic policymaking.

The achievement of macroeconomic goals namely; full employment, stability of price level, high and sustainable economic growth, and external balance, from time immemorial, has been a policy priority of every economy whether developed or developing given the susceptibility of macroeconomic variables to fluctuations in the economy (Omitogun and Ayinla, 2007). The realization of these goals undoubtedly is not automatic but requires policy guidance. This policy guidance represents the objective of economic policy. Fiscal and monetary policy instruments are the main instruments of achieving the macroeconomic targets.

The basic fiscal policy instruments are public expenditure and tax while the monetary policy instruments include the devices of reserve requirements, discount rates and open market policy. Given the fact that both monetary and fiscal policies impact on economic growth and development, it is not surprising that they are entwined. This relationship has been explicitly explained thus: Fiscal and monetary policies are inextricably linked in macroeconomic management; development in one sector directly affects developments in the other. Undoubtedly, fiscal policy is central to the health of any economy, as government's power to tax and to spend affects the disposable income of citizens and corporations, as well as the general business climate (Ezeoha and Chibuike, 2005). In this regard, the interrelationship between public spending and private sector performance is of paramount importance. On one hand, Government expenditure can provide an impulse for private sector growth, while on the other hand; it can be harmful if it results in budget deficits and leads to competition for scarce financial resources from the banking sector as the government seeks to finance the deficit. In such circumstances, the crowding out of the private sector by the Government sector can outweigh any short-term benefits of an expansionary fiscal policy. The key to all these therefore lie in striking a good balance in fiscal management. Having enough expenditure outlays to meet the needs of Government and support growth, but not so much as to deny the private sector the resources it needs to invest and develop.

Besides that Nigeria is a developing country, it has been specifically observed that the major challenge to Nigeria economy is the volatile macroeconomic environment driven by external term of trade shocks and the country's large reliance on oil export earnings (World Bank, 2003). From 
historical perspective, Nigeria discovered oil in 1956 but began to export oil in 1958. Since early 1970s oil has become the dominant factor in Nigerian economy and its revenue has formed the major basis of government income. Over the time, various oil price developments in the world oil market has led to instability in fiscal stance and has been transmitted to the rest of the economy, with negative implications for, in particular, the real exchange rate and growth performance (Okonjo-Iweala and Osafo, 2007).

It has, for instance, recently been noted that: "Government deficits have posed significant problems for the country since the oil boom of the "70s. Expansionary fiscal policies prompted by the favorable oil proceeds in the international market resulted in large fiscal deficits and the rapid build- up of external and domestic debts. With expenditure rising faster than revenue, deficits grew from an average of 5.0 percent of GDP in 1983-86 to 10.3 percent in 1991-94 before declining to 4.9 percent in 1999-2002. The deficit problem has remained persistent because of "government's inability to reduce the level of expenditure to sustainable levels" (Alade, 2003; Ezeoha and Chibuike, 2005).

Although since the drastic oil price fall of 1980s, fiscal policy in Nigeria has lost the desirable characteristics required for its effectiveness as a tool for aggregate demand management (Phillip, 1997); it still has a yearly contribution to the economy either positively or otherwise.

Ezeoha and Chibuike (2005) observed that Government fiscal recklessness resulting in deficit financing can also cause inflation, which contradicts the fundamental monetary policy objective of price stability. This has the potentials of destabilizing the macro- economic environment thereby retarding economic productivity and development. Therefore the need for a more stable macroeconomic environment through sound fiscal and monetary actions is still very paramount in the world of research. Besides the challenges posed by globalization to the domestic economy, it has been empirically argued that instability and uncertainty in any economy impede long term growth and have high welfare cost.

The specific objectives of this study are to;

i. Examine the trend of variation in fiscal spending components and real GDP in Nigeria between 1970 and 2010; and

ii. Determine the cyclical effects of fiscal instability on real GDP fluctuations in Nigeria.

\subsection{Literature Review}

Fiscal policy has been defined as the planning of revenue and expenditure levels and pattern by government to influence the circular flow, or specifically to promote full employment production, price stability and national welfare (Fashola, 2001). This constitutes basically the objectives of fiscal policy. These objectives are to be achieved through expansionary or contractionary fiscal policies.

Governments directly and indirectly influence the way resources are used in the economy. Fiscal policy that increases aggregate demand directly through an increase in government spending is typically called expansionary or "loose." By contrast, fiscal policy is often considered contractionary or "tight" if it reduces demand via lower spending (Horton and El-Ganainy, 2009).

Horton and El-Ganainy (2009), review that, besides providing goods and services, fiscal policy objectives vary. In the short term, governments may focus on macroeconomic stabilization. In an oil-producing country, fiscal policy might aim to moderate pro-cyclical spending; moderating both bursts when oil prices rise and painful cuts when they drop.

Richard et al (2009) also noted that fiscal policy affects aggregate demand, the distribution of wealth, and the economy's capacity to produce goods and services. In the short run, changes in spending or taxing can alter both the magnitude and the pattern of demand for goods and services. With time, this aggregate demand affects the allocation of resources and the productive capacity of an economy through its influence on the returns to factors of production, the development of human capital, the allocation of capital spending, and investment in technological innovations.

Many researchers (Adeoye, 2006; Omitogun and Ayinla, 2007) believe that fiscal policy, together with monetary policy, is the most important means of regulating the rate of inflation in an economy and preventing or controlling depression.

Omitogun and Ayinla (2007) noted that when there is economic recession or depression, government plans for budget deficit, which is often referred to as expansionary fiscal policy. Also, government can plan for budget surplus (which is also referred to as contractionary fiscal policy) particularly in such a situation where the government deems it necessary to reduce her participation in terms of production in the domestic economy. The government does this by reducing public expenditure and increasing taxes.

According to Gray et al (2007), government can use fiscal policies to reduce the demand for goods and services. It can prevent depressions by encouraging spending, while rate of inflation can be controlled by discouraging spending. Tax rates, which are determined by fiscal policy, influence level of spending by influencing the amount of money people have for spending. Government can also decrease or increase its own spending to manage inflation and depression.

Macroeconomics has long featured two general views of the economy and the ability of fiscal policy to stabilize or even affect economic activity. The equilibrium view sees the economy quickly returning to full capacity whenever disturbances displace it from full employment (Blinder, 2006).

According to (Blinder, 2006), changes in fiscal policy, or even in monetary policy for that matter, have little potential for stabilizing the economy. Instead, inevitable delays in recognizing economic disturbances, in enacting a fiscal response, and in the economy's reacting to the change in policy can aggravate, rather than diminish, business-cycle fluctuations. 
Fiscal policies that increase the deficit will result in future taxes being higher than they otherwise would have been, but, depending on the policies' effects on incentives for investing in human or physical capital, they might also raise future living standards. Policies that absorb slack resources or foster investment might reduce government saving, as reflected in the greater budget deficit, while they increase total saving, as reflected in the greater rate of capital formation (Horton and El-Ganainy, 2009).

Blinder (2006) takes issue with that conclusion in "the Case Against Discretionary Fiscal Policy.” Blinder (2006) reminds the reader that views on the use of discretionary fiscal policy as a tool for macroeconomic stabilization have undergone a sea change since the early 1960s, when the prevailing wisdom was that discretionary stabilization policy was effective and desirable for taming the business cycle, and that fiscal policy was the most important tool with which to conduct stabilization policy.

Then, beginning in the late 1960s, theoretical and empirical work raised serious doubts about fiscal policy's ability to accomplish countercyclical stabilization; while large deficits in the 1980s made it unlikely any would be attempted. Blinder begins by reviewing the intellectual and policy developments that led to the diminished role of fiscal policy, and then turns his attention to a critical analysis of the arguments against the use of discretionary fiscal policy as a stabilization tool.

After discussing the theoretical assumptions underlying Ricardian equivalence, Blinder (2006), evaluates the empirical research on this topic. He concluded that the weight of the evidence supports the view that both temporary and permanent tax changes do affect consumption spending. In the final analysis, Blinder concluded that monetary policy should be relied upon as the primary policy tool for macroeconomic stabilization, but that discretionary fiscal policy can play an important stabilization role under unusual circumstances. When a recession is unusually long or deep, or when short-term nominal interest rates approach zero, then it is appropriate to supplement monetary policy with fiscal stimulus.

\section{Methodology}

This study used secondary data sourced from 2010 Central Bank statistical bulletin, National Bureau of statistics, Federal Office of Statistics, 2010 Penn World Table and 2007 World Bank Development Indicators. The data covered the period 1970 to 2010 focusing on federal government finance, national income account and productivity. The study used both descriptive and quantitative methods for the analysis of the data. The first objective, the trend of variation in fiscal spending components and real GDP in Nigeria between 1970 and 2010, was examined using the descriptive method.

The second objective; the cyclical effect of fiscal instability was measured using the Hodrick-Prescott (HP)-filtered fiscal spending components and output (real GDP) with the correlation technique as used by Talvi and Vegh (1998) and, Stein et al (1999). In addition, to take care of possible omitted variables bias and for the robustness of findings, stability test of model specification for the sample period was carried out using CUSUM of square diagnostic test. The CUSUM of squares test is an ordinary least square (OLS) stability test based on the test statistic.

\section{Specification of the Model}

Based on the real business cycle (RBC) theoretical framework and the intuition from the empirical literature reviewed earlier, fiscal instability can impact on real business cycles (that is, economic fluctuations), which can equally impact on the long-term economic growth (Ariyo 1993). The possible effect of fiscal instability will then depend on model specification. The modeling approach will be rested on three key considerations;

First, it is possible to explain business cycles through growth theory. Secondly, fiscal instability and economic growth (or real GDP fluctuation about its mean growth path) and fiscal spending are jointly determined and thirdly, both economic fluctuations and fiscal spending might respond to structural factors such as political instability and the degree of trade and financial openness of the economy.

Therefore, to specify the economic fluctuation equation starting with the popular Cobb Douglas production function in which output depends on the productivity of the available physical and human capital and the level of technology, we have;

$$
Y_{t}=A K_{t}^{\alpha} L_{t}^{\beta}
$$

Where $\alpha, \beta>0$ and $\alpha+\beta=1$

Also, $Y_{t}$ represents the real output, $K_{t}$ is the capital, $L_{t}$ represents labour and the level of technology is $A, \alpha$ and $\beta$ are the parameters representing the output elasticity of capital and labour inputs respectively.

According to Finn (1998), government spending can directly enter into the economy through government investment in public capital, hence we can split capital into private and public capitals such that equation (1) becomes;

$$
Y_{t}=A\left(K_{p} K_{G}\right)^{\alpha} L_{t}^{\beta}
$$


By opening the bracket, equation (2) will become;

$$
Y_{t}=A K_{p}^{\omega} K_{G}^{\varphi} L_{t}^{\beta}
$$

Where $\varphi, \omega>0$ and $\varphi+\omega=\alpha$

By taking the log-linear of variables in equation (3) and using the lower case of the symbol to represent the logarithm of the variables, then we have;

$$
y_{t}=a+\omega k_{p_{t}}+\varphi k_{g_{t}}+\beta l_{t}+\varepsilon_{t}
$$

Where $y_{t}, k_{p}, k_{g}$, and $l$ are the logarithm of the real GDP, private capital, public capital and labour force respectively and $\varepsilon$ is the error term; all in time t.

According to Hodrick and Prescott (1997), the conceptual framework of a given time series data, $Y_{t}$, is the sum of a growth $\left(y_{t}^{g}\right)$ and a cyclical $\left(y_{t}^{c}\right)$ components. Thus;

$$
Y_{t}=y_{t}^{g}+y_{t}^{c}, \quad \text { for } \mathrm{t}=1,2,3 \ldots, \mathrm{T}
$$

The interest of this study will be the cyclical components of real GDP $\left(y_{t}^{c}\right)$, which is about its long-term growth paths, representing the real business cycles or the fluctuations in the economy. Therefore, equation (5) is re-expressed as follows;

$$
y_{t}^{c}=Y_{t}-y_{t}^{g}
$$

The measure of the smoothness of the growth path is the sum of the squares of its second difference. The cyclical component $\left(y_{t}^{c}\right)$; which are the deviations from the mean growth path $\left(y_{t}^{g}\right)$, over long time periods will have their average near zero. These considerations lead to the following programming problem to determine $y_{t}^{c}$;

$$
\operatorname{Min}_{\left\{y_{t}\right\}}\left\{\sum_{t=-1}^{T}\left(Y_{t}-y_{t}\right)^{2}+\lambda \sum_{t=1}^{T}\left[\left(y_{t}-y_{t-1}\right)-\left(y_{t-1}-y_{t-2}\right)\right]^{2}\right\}
$$

where $\lambda$ is the smoothness parameter. According to Hodrick and Prescott, the cyclical component series, $y_{t}^{e}$ can be obtained using equation (7) and taking $\lambda=100$ for annual data. This method of generating the cyclical series is called the HP-filter technique. Thus, equation (4) is re-expressed for $y_{t}^{c}$ as follows

$$
y_{t}^{c}=a+\omega k_{p_{t}}+\varphi k_{g_{t}}+\beta l_{t}+v_{t}
$$

Also domestic investment and fiscal spending will be proxies for the private and the public capital stocks respectively. Darby and Mélitz (2007) pointed out that in the composition effect of domestic expenditure, even if the response of fiscal spending to business cycle is muted, it mechanically contributes to the stability of aggregate demand. In place of fiscal spending, the cyclical series of fiscal spending and fiscal spending components are required for this study. The series will be equally generated using the HP-filter technique as discussed earlier.

Examining the effect of globalization on the domestic economy, Rodrik (1998) stressed the importance of trade openness $\left(\right.$ TROPEN $N_{t}$ ) as a source of macroeconomic fluctuation while Carmigani (2007) and Ayadi (2009) pointed to financial openness (which is proxied by foreign direct investment $\left(F D I_{t}\right)$ ) as having a stabilizing effect by favouring risk diversification. Also, Blanchard and Simon (2001) pointed to the fact that inflation ( $\left.I N F L R_{t}\right)$ is an important explanatory variable of real output fluctuation. In addition, population $\left(P O P_{t}\right)$ is an important demographic variable in economic fluctuation model (Bejan, 2006). Interest rate $\left(I N T R_{t}\right)$ is added as an instrument used by monetary authority for economic 
management. Also the effect of political instability $\left(P O L S T A B_{t}\right)$ on real output fluctuation is examined using dummy variable in which military regime will be assigned 1 and democratic regime takes 0 . This idea takes after the work of De Haan and Sturm (1994) and as adopted by Foye (2008). Based on this, equation (8) can be re-expressed as follows;

$$
\begin{aligned}
\text { CRGDP }_{t}=a & +\varphi \text { CTGOV }_{t}+\text { LIINVEST }_{t}+\alpha_{2} \text { LTROPEN }_{t}+\alpha_{3} \text { FDI }_{t}+\alpha_{4} \text { LINFLR }_{t} \\
& +\alpha_{5} \text { LINTR }_{t}+\alpha_{6} \text { LPOP }_{t}+\alpha_{7} \text { POLSTAB }_{t}+\beta L A B O R_{t} \\
& +\epsilon_{t} \ldots \ldots \ldots \ldots \ldots \ldots \ldots \ldots(9)
\end{aligned}
$$

Where $C R G D P_{t}$ represents the real output fluctuation, $C T G O V_{t}$ is the cyclical component of total fiscal spending and $I N V E S T_{t}$ is the domestic investment. Other denotations are as defined earlier. One of the parameter of interest to this study is $\varphi$. By disaggregating the cyclical series of total fiscal spending into recurrent and capital expenditure represented by $\mathrm{CRGOV}_{t}$ and $\mathrm{CCGOV}_{t}$ respectively, equation (9) becomes;

$$
\begin{aligned}
\text { CRGDP }_{t}=a & +\varphi_{1} \text { CCGOV }_{t}+\varphi_{2} \text { CRGOV }_{t}+\omega \text { LINVEST }_{t}+\alpha_{2} \text { LTROPEN }_{t}+\alpha_{3} \text { FDI }_{t} \\
& +\alpha_{4} \text { LINFLR }_{t}+\alpha_{5} \text { LINTR }_{t}+\alpha_{6} \text { LPOP }_{t}+\alpha_{7} \text { POLSTAB }_{t}+\beta L A B O R_{t} \\
& +\epsilon_{t} \ldots \ldots \ldots \ldots \ldots \ldots \ldots \ldots(10)
\end{aligned}
$$

$\varphi_{1}$ and $\varphi_{2}$ are other parameters of interest in this study to reveal the effect of recurrent and capital fiscal spending respectively.

Equations (9) and (10) are the endogenous equations denoting the required structural model to be estimated using ordinary least square (OLS) technique after checking for the time series properties of the variables in use.

\section{Results and Discussion}

Taking a descriptive examination of the trend of variation in real gross domestic product and fiscal spending in Nigeria for the study period of 1970 to 2010 , this study employed line graphs for the trend analysis of the subject matter.

In figure 1, between 1970 and 1985, both the real gross domestic product (CRGDP) and real total fiscal spending (CTGOV) were highly volatile. This was revealed by the trend and pattern of movement in the plotted variables. For this period, there was highly unstable movement in their variation. Although, in the first decade, there was a downward trend in real GDP cycles until a very sharp upward trend between 1980 and 1982, while total fiscal spending appears to be more volatile at this period.

The high instability in total fiscal spending and real GDP between 1970 and 1987 could be explained by the economic crises of 1970s althrough to 1980s. The economic downturn experienced by Nigeria at this period reflected the various oil price development in the world oil market. The discovery of crude oil in 1956 and its exports in 1958 by Nigeria marked the process of shifting of Nigeria economy from agriculture- based to oil- based economy. Since early 1970s, oil has become the dominant factor in the Nigerian economy and the crude oil revenue formed the basis of government income.

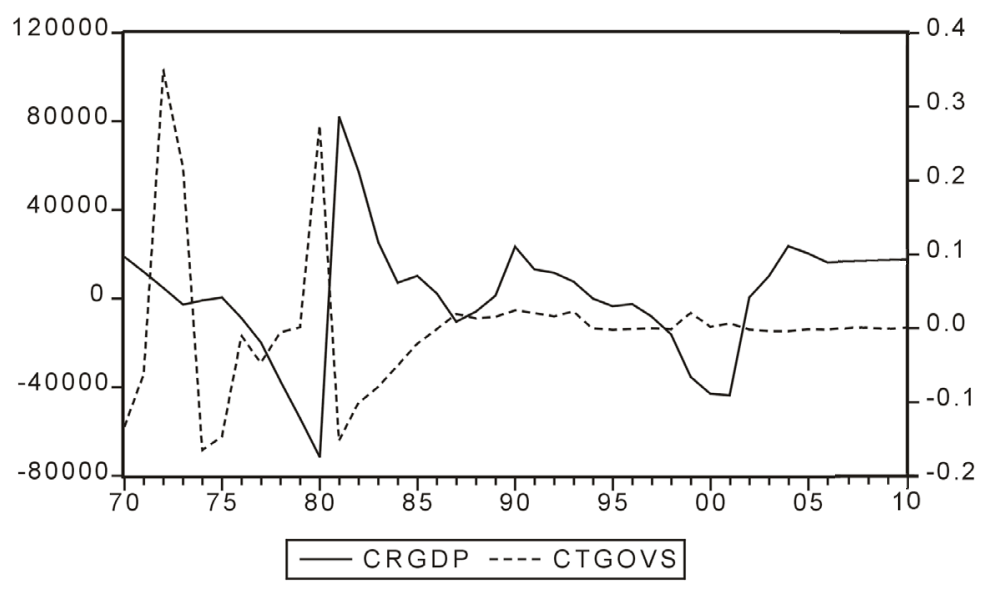

Figure 1. Cycles/Variation in Real Gross Domestic Product and Total Fiscal Spending 
The fiscal stance became volatile due to high fluctuation in the price of oil at the world oil market, affecting the revenue of the government and consequently, the fiscal spending. This view is supported by Bannagaard (2003) and Budina et al (2007). Therefore, the sharp oil price fall of 1980s transmitted into distabilizing the macroeconomic environment. Also from the same figure, between 1987 and 1998 the variation in both total fiscal spending and real gross domestic product(GDP) were relatively stable. This could partly be as a result of the introduction of Structural Adjustment Programme(SAP) in 1986. This was an economic management strategy to revive the economy from the oil price shocks of early 1980s.

However, total fiscal spending appears to be countercyclical (that is, opposite co-movement in variation between total fiscal spending and real gross domestic product) between 1970 to 1986. But from 1987 to 2010, the variation in total fiscal spending was relatively stationary while real output was still relatively unstable. Therefore, the total fiscal spending remained neutral to correcting fluctuations in real gross domestic product at the period. Figure 2 showed the variation in real gross domestic product (CRGDP) and capital fiscal spending (CCGOVS). Again, between 1980 and 1985, capital fiscal spending was more countercyclical than recurrent fiscal spending while between 1987 to 2010, the two fiscal spending components exhibit similar trend of variation. The study also showed that the real total fiscal spending cycles (CTGOV) co-efficient is negative but not significant at $1 \%, 5 \%$,and $10 \%$ levels (Table 1).This runs contrary to the a priori expectations as CTGOV was expected to buoy up the GDP and not to reduce it. This might be attributed to huge wastages and sharp practices that often characterize government businesses/expenditures.Furthermore, it was noted that the countercyclical degree of responsiveness of the total fiscal spending to economic fluctuations in Nigeria is quite low.Thus,there is a minimal overbearing effect of the real total fiscal spending by government on the GDP particularly between 1987 and 1998 when the variations in both the total fiscal spending and the GDP were relatively stable due to the introduction of the Structural Adjustment Programme (SAP) by the government of Nigeria.

However, there was a noticeable countercyclical movement between fiscal spending and the real GDP between 1970 and 1986.

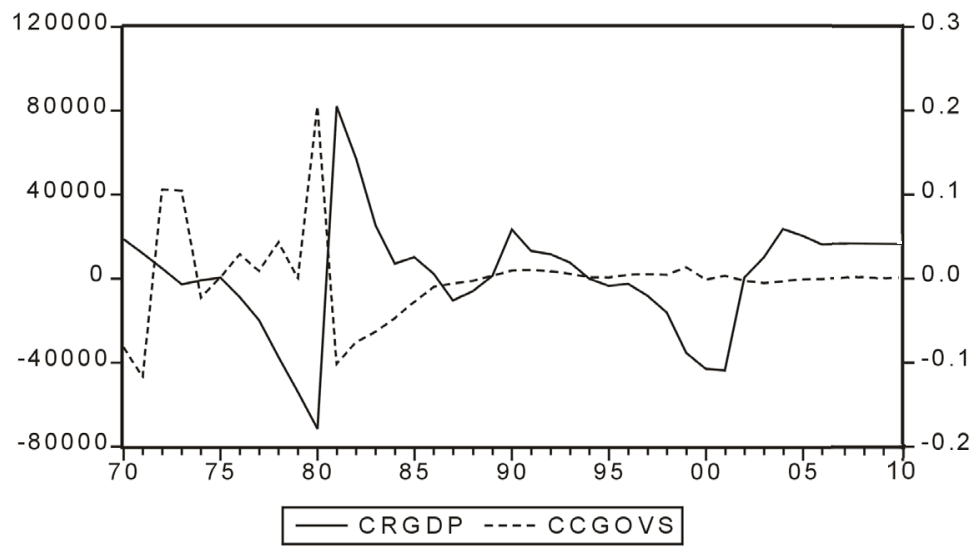

Figure 2. Cycles/Variation in Real Gross Domestic Product and Capital Fiscal Spending

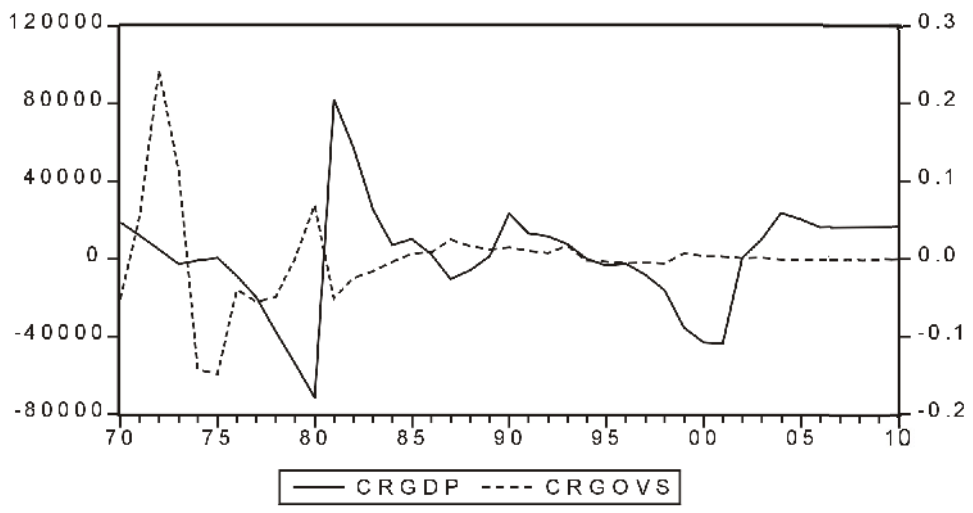

Figure 3. Cycles/Variation in Real Gross Domestic Product and Recurrent Fiscal Spending

In other word, their cycles were relatively stationary. This implies that both recurrent and capital fiscal spending were neutral in correcting the instability in the real output at that period.

In summary, figure 4 graphically showed the trend of variation in real GDP, total, recurrent and capital fiscal spending. The 
diagram revealed that all the variables were highly volatile between 1970 and 1987, while the variation in fiscal spending categories were relatively stationary (that is, neutral or acyclical in nature) between 1987 and 2010, but the cycles in real gross domestic product were still relatively unstable.

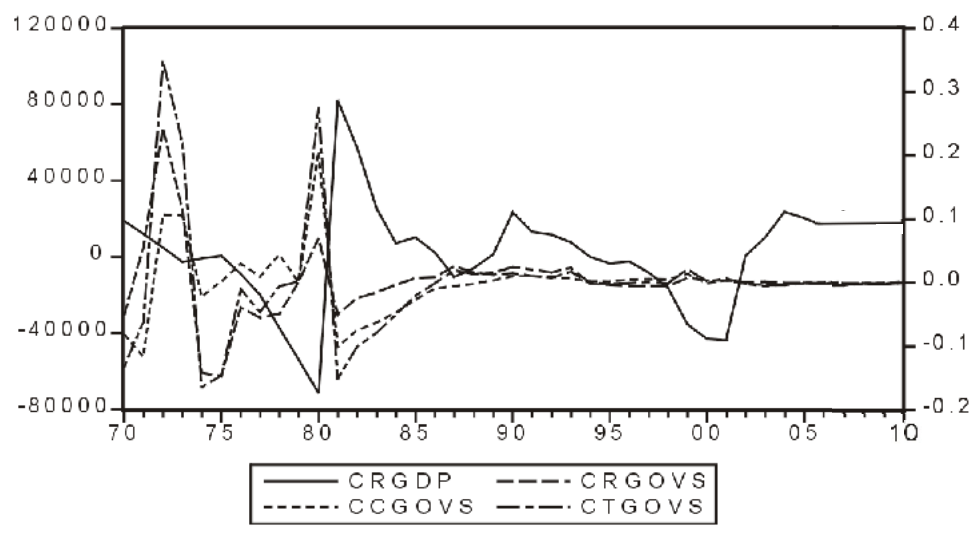

Figure 4. Cycles/Variation in Real GDP, Total, Recurrent and Capital Fiscal Spending

Therefore, it can be deduced that from 1987, fiscal spending in Nigeria became ineffective instrument of controlling fluctuations or instability in the economy. This conclusion supported the view of Phillip (1997) that fiscal policy in Nigeria has lost the desirable characteristics required for its effectiveness as a tool for aggregate demand management since the drastic oil price fall of 1980 s.

\section{Effect of Total Fiscal Spending on Economic Growth}

The OLS results for the adjusted sample period of 1972 to 2010 to determine the cyclical effect of total fiscal spending is shown in Table 1. From the table, R-squared for CRGDP is 0.72245 and this measures the goodness of fit of the model. This implies that $72 \%$ of variation in the dependent variable (CRGDP) is explained by the independent variables (CTGOV, FDI, LINFLR, LINTRD, LINVEST, LLABOR, LPOP, TROPEN, POLSTAB, CRGDP(-1), LINVEST(-1), LINTRD(-1) and LTROPEN(-1). The lagged values of CRGDP, LINVEST, LINTRD and LTROPEN were included in the model to obtain more useful information relative to the real business cycles over the study period. The F-statistic result of 4.404443 with the probability value of 0.001129 shows that these independent variables are jointly significant in explaining the variation in the dependent variable. The Akaike Information Criterion (AIC) value of 7.184208 and Schwarz Information Criterion value of 7.800021 , which are at their minimum values, show the model selection criterion of the estimated model.

Table 1. OLS Results of Total Fiscal Spending

Dependent Variable: CRGDP

Sample (adjusted): $1972-2010$

Included observations: 39 after adjusting endpoints

\begin{tabular}{lllll}
\hline \hline Variable & Coefficient & Std. Error & t-Statistic & Prob. \\
\hline \hline C & 1380.939 & 456.8679 & 3.022623 & 0.0063 \\
CTGOV & -0.084556 & 0.119599 & -0.706996 & 0.4870 \\
FDI & 1.478716 & 1.165719 & 1.268502 & 0.2179 \\
LINFLR & -0.372830 & 2.057094 & -0.181241 & 0.8578 \\
D(LINTRD) & -3.696240 & 7.651002 & -0.483105 & 0.6338 \\
D(LINVEST) & 8.970957 & 3.100998 & 2.892926 & 0.0084 \\
LLABOR & -386.0478 & 124.1036 & -3.110689 & 0.0051 \\
LPOP & 13.17875 & 7.568883 & 1.741175 & 0.0956 \\
D(LTROPEN) & -12.86427 & 3.707408 & -3.469883 & 0.0022 \\
D(POLSTAB) & 3.492981 & 6.407185 & 0.545166 & 0.5911 \\
CRGDP(-1) & 0.313624 & 0.148724 & 2.108767 & 0.0466 \\
D(LINVEST(-1)) & 6.170952 & 3.288614 & 1.876460 & 0.0739 \\
D(LINTRD(-1)) & -15.49993 & 8.422317 & -1.840341 & 0.0792 \\
D(LTROPEN(-1)) & -3.130549 & 3.484447 & -0.898435 & 0.3787 \\
\hline \hline
\end{tabular}


R-square $=0.722425$

F-stat. $=4.404443$

Durbin-Watson Statistics. $=2.021657$

S.E. of regression $=7.788507$
Adjusted R-square $=0.558403$

$\operatorname{Prob}($ F-stat $)=0.001129$

Akaike Infor Criterion $=7.228477$

Schwarz Infor Criterion $=7.844290$
The real total fiscal spending cycles (CTGOV) coefficient is negative but not significant at $1 \%, 5 \%$ and, even, $10 \%$ levels of significance with a t-statistics value of -0.706996 and t-statistics probability value of 0.4870 . Specifically, the real total fiscal spending cycles (CTGOV) co-efficient is negative but not significant at all levels. The negative co-efficient could indicate that a huge percentage of government spending did not translate to economic growth probably because of high incidence of corruption, internal and external debt servicing and other forms of annual spending of government that did not necessarily lead to development processes.Again, the rate of inflation (LINFLR) had a negative co-efficient of -0.372830 but with non-significant t-statistics value of -0.181241 .Thus, both the total fiscal spending by government and rate of inflation had negative relationships with the nation's GDP for the period of study.

Since the t-calculated value is less than the t-tabulated, we will accept the null hypothesis $\left(\mathrm{H}_{0}\right)$ and reject the alternative hypothesis $\left(\mathrm{H}_{1}\right)$. This was further corroborated by earlier findings of Philips (1997), which conclude that fiscal policy in Nigeria has lost the desirable characteristics required for its effectiveness as a tool for stabilizing the economy. Although, the negative sign revealed a countercyclical movement in the total fiscal spending, it does not significantly reduce the instability in the economy. A $1 \%$ rise in the total fiscal spending will reduce the instability in real output by $0.08 \%$. This further means that the countercyclical degree of responsiveness of total fiscal spending to economic fluctuation in Nigeria is low and insignificant at 1\%,5\%, even, $10 \%$ levels of significance.

Foreign direct investment (FDI) has a positive effect on real GDP fluctuations, with a non-significant t-statistics value of 1.268503 at both $1 \%$ and $5 \%$ levels of significance. A $1 \%$ rise in foreign direct investment will cause a $1.48 \%$ increase in the level of economic instability in Nigeria. Inflation rate (LINFLR) has a negative co-efficient but with non-significant $t$-statistics level of -0.181241 . A $1 \%$ rise in inflation rate will reduce the output fluctuations by $0.37 \%$. Also, interest rate (LINTRD) has a negative coefficient but with non-significant $t$-statistic value of $-0.483105 .1 \%$ rise in interest rate will reduce the economic instability by $3.70 \%$.

In addition, the domestic investment (LINVEST) has a positive coefficient with a significant $t$-statistic value of 2.892926 at both $1 \%$ and $5 \%$ levels of significance. A $1 \%$ rise in the domestic investment will lead to about $8.97 \%$ increase in economic fluctuations in Nigeria. The size of labour force (LLABOR) has a negative coefficient but with a significant $\mathrm{t}$-statistic value of -3.110689 at both $1 \%$ and $5 \%$ levels of significance respectively. A $1 \%$ rise in the labour force will reduce the real output fluctuation by $386.0 \%$.

The population size (LPOP) has a positive coefficient but only significant with t-statistic value 1.741175 at $10 \%$ level of significance. A $1 \%$ rise in the population size will increase the real GDP fluctuations by $13.18 \%$. Trade openness (LTROPEN) has a negative but significant effect on economic instability with a t-statistic value of -3.469883 . This result is significant at both $1 \%$ and $5 \%$ levels of significance. A $1 \%$ increase in trade openness will reduce the instability in the economy by $12.86 \%$. Also, political instability (POLSTAB) has a positive effect but with non-significant $t$-statistic value of_0.545166. $1 \%$ rise in political instability will increase the instability in the economy by $3.49 \%$.

By examining the lagged value of the dependent variable (CRGDP (-1)), the immediate past value of real gross domestic product cycles is positively and significantly related to its own current year value at $5 \%$ level of significance. This is based on t-statistic value of 2.108767. A $1 \%$ rise in the immediate past value of real gross domestic product cycles will increase the current real output fluctuation by $0.31 \%$. Also, the immediate past value of domestic investment (LINVEST (-1)) has a positive coefficient but with non-significant $t$-statistic value of 1.876460 at both $1 \%$ and $5 \%$ levels. It is only significant at $10 \%$ level of significance. $1 \%$ rise in the immediate past value of domestic investment will increase the instability in the economy.

Furthermore, both lagged value of interest rate (LINTRD(-1)) and trade openness (LTROPEN(-1)) are negatively related with economic instability but with non-significant $t$-statistic values of -1.840341 and -0.898435 at both $1 \%$ and $5 \%$ levels of significance. However, the lagged value of interest rate is significant at $10 \%$ level. A $1 \%$ rise in lagged value of interest rate will reduce real output fluctuation by $15.50 \%$ while $1 \%$ rise in trade openness will reduce real output fluctuation by $3.13 \%$.

\section{Recommendations and Conclusion}

\subsection{Recommendations}

In view of the above points, the following recommendations 
were made:

(1). For the Nigerian government to reduce the instability in the macroeconomic environment vis-à-vis fiscal spending channel, the government should increase its capital fiscal spending at the expense of the recurrent fiscal spending. This is because the countercyclical strength of capital fiscal spending could increase if reinforced.

(2). The government should embrace more fiscal discipline as against the increased political spending which will usually aggravate the instability in fiscal spending in Nigeria.

(3). The federal government should put in place policies that would promote international trade and the level of employment, especially at the time of economic downturn to revive the economy and increase the level of economic growth in Nigeria.

(4). As a major foreign exchange earner for the Nigerian government, the oil sector should be properly fortified so as to further buoy up the revenue generation capacity and the quantum of spendable funds from the sub-sector. To achieve this, all cases of pipeline vandalism, oil bunkering, oil spillage and all other forms of human deliberate efforts towards negatively impairing on the production capacities of the sub-sector should be done. Turn-over maintenance and repairs of the four refineries should also continually doe to ensure optimal production levels. With these, the nation will have sufficient income to implement its numerous fiscal spending and even provide employment for the teaming unemployed youths.

\subsection{Conclusion}

This study examined the effect of fiscal instability on economic growth in Nigeria. Overall, the study found that both total and capital fiscal spending had negative relationship with economic growth while recurrent fiscal spending was on the contrary. However, their effects were insignificant. Only trade openness and size of labor force had significantly countercyclical effect on the economy over the study period.

Conclusively, the evidence provided in this study based on our earlier empirical findings showed that the real gross domestic product, real total, recurrent and capital fiscal spending were volatile and that these fiscal spending categories were more volatile than real gross domestic product. Also, both total and capital fiscal spending had countercyclical effect on economic instability but with non-significant except for capital fiscal spending that was significant at ten percent level. Recurrent fiscal spending was insignificantly pro-cyclical in Nigeria. Therefore, this study revealed that fiscal spending could not serve as an effective policy instrument to reduce economic instability in Nigeria.

\section{REFERENCES}

[1] Adefeso H.A and Mobolaji H.I (2010) "The Fiscal-Monetary Policy and Economic Growth in Nigeria", Further Empirical Evidence. Pakistan Journal of Social Sciences. Volume: 7; Issue: 2, Pg.: 137-142.

[2] Adeoye, T. (2006) "Fiscal Policy and Growth of Nigerian Economy: An Empirical Perspective" NISER Monograph Series No 3, NISER Ibadan.

[3] Alade, S. (2003) "Fiscal Adjustment in Nigeria: Issues in Capital Expenditure", The Bullion, Volume 27, Number 2, pp.8-16.

[4] Ariyo, A. (1993) "An Assessment of the Sustainability of Nigeria's Fiscal Deficit, 1970 - 1990", Journal of African Economies, Vol. 2, No. 2, pp. $263-282$.

[5] Ayadi,F.S.(2009): 'Foreign Direct Investment and Economic Growth in Nigeria: Repositioning African Business and Development for the 21st Century '.Simon Sigue (Ed.),Proceedings of the 10th Annual Conference.Pp.261

[6] Bannagaard, T. (2003) 'Fiscal Policy in Nigeria: Any Role for Rules?' International Monetary Fund Working paper, No. 155 .

[7] Bejan,M.(2006):Trade openness and output volatility.Mimeo.ITAM.PP.17-24.

[8] Blanchard,O.and Simon,J.(2001):The Long and Large Decline in US output Volatility.Brooking paper on economic activity. Volume 1 Number 4.Pp 135-164.

[9] Blinder, A. J. (2006) "The case against the case against discretionary fiscal policy". In The macroeconomics of fiscal policy. Cambridge: MIT Press.

[10] Carmigani,F.(2007):Public Expenditure and Growth Volatility:Do Globalization and Institution Matter? United Nations Economic Commission for Africa,Central Africa Office, Yaounde,Cameroun.

[11] Central Bank of Nigeria (2010) Annual Report and Statement of Accounts 31st Dec. 2010, Abuja. Pages 9-20.

[12] Darby.J.and Melitz,J.(2007):Labour Market Adjustment,Social Spending and the Automatic Stabilizers in the OECD.Discussion Paper No.6230.

[13] De Haan,J. and Sturm,J.F.(1994):Political and Economic Determinants of OECD Budget Deficits and Government Expenditures :A Re-investigation.European Journal of Political Economy.Volume 13.Pp.739-750.

[14] Ezeoha, A. and Chibuike, U. (2005) "Rethinking Monetary and fiscal policies in Nigeria".

[15] Fashola, M.A (2001) Macroeconomics Theory; Highlights and Policy Extensions for Less-Developed Economies. 3rd Edition; Concept Publication.

[16] Fatás, A. (2002) "The Effects of Business Cycles on Growth" Central Bank of Chile Working Papers No 156.

[17] Fatás,A. and Mihov, I. (2003) "The Case for Restricting Fiscal Policy Discretion" Quarterly Journal of Economics, 


\section{Vol. 118 pp 1419-47}

[18] Finn, M. G. (1998) "Cyclical Effects of Governments Employment and Goods Purchases" International Economic Review, Vol. 39, No 3.

[19] Foye,V.O.(2008):The Macro-economic Determinants of Public Capital Spending in Nigeria (1970-2006).An M.Sc. Research Proposal presented at the Department of Economics,Obafemi Awolowo University,Ile-Ife,Osun State,Nigeria.

[20] Gray, C. Tracey, L. and Varoudakis A. (2007): Fiscal Policy and Economic Growth. Lessons for Eastern Europe and Central Asia. World Bank; Washington, DC.

[21] Hnatkovska, V. and Loayza, N. (2005) "Volatility and Growth", The World Bank Working Paper Series, No 3184.

[22] Hodrick, R. J. and Prescott, E. C. (1997) "Postwar U. S. Business Cycles: An Empirical Investigation" Journal of Money, Credit and Banking, Vol. 29, No. 1.

[23] Horton, M. and El-Ganainy, A. (2009) "What is Fiscal Policy?" Finance and Development; IMF's Fiscal Affairs Department.

[24] Martin, P. and Rogers C. A. (2000) "Long term Growth and Short term Economic instability", European Economic Review, Vol. 44, no. 2, pp. $359-381$.

[25] Mobarak, M. A. (2001) "Volatility and Its Implications for Economic Development",Department of Economics, University of Maryland, College Park, MD 20742.

[26] Obiyeluaku, M. (2006) Fiscal Policy in Nigeria; fixed or Variable? University of KwaZulu-Natal.
[27] Okonjo-Iweala N. and Osafo K. P. (2007) 'Nigeria's Economic Reforms: Progress and Challenges', The Brooking Institution, Washington, Dc.www.brookings.edu/global.

[28] Omitogun, O. and Ayinla, T.A (2007) "Fiscal Policy and Nigeria Economic Growth". Journal of research in national development volume 5 no 2, December 2007.

[29] Philips, A. O (1997) "Nigerian Fiscal Policy, 1998 -2010", Nigerian Institute of Social Economic Research (NISER), Monograph Series No. 17, Ibadan.

[30] Ramey, G., and V. Ramey (1995) "Cross-Country Evidence on the Link between Volatility and Growth", The American Economic Review, vol. 85, no 5, pp. 138-151.

[31] Richard, W. K., Geoffrey, M. B. and Robert, K. T. (2009); "The Macroeconomics of Fiscal Policy", Cambridge: MIT Press.

[32] Rodrik, D. (1998) "Why Do More Open Economies Have Bigger Government?" Journal of Political Economy Vol. 106, pp. $997-1032$.

[33] Servén, L. (1998) "Macroeconomic Uncertainty and Private Investment in Developing Countries: An Empirical Investigation", The World Bank (Policy Research Working Paper, no 2035).

[34] Talvi, E. and Vegh, C. (1998) "Tax base variability and procyclical fiscal policy”. NBER Working Paper No 7499.

[35] World Bank, (2003) "Nigeria Policy Options for Growth and Stability", Report No. 26215-NGA, Washington DC: The World Bank. 